\title{
Who does better for the economy? Presidents versus parliamentary democracies
}

\author{
Richard McManus $^{1} \cdot$ F. Gulcin Ozkan ${ }^{2}$
}

Received: 2 August 2017 / Accepted: 12 March 2018 / Published online: 2 May 2018

(C) The Author(s) 2018

\begin{abstract}
Are certain forms of government associated with superior economic outcomes? This paper attempts to answer that question by examining how government systems influence macroeconomic performance. We find that presidential regimes consistently are associated with less favorable outcomes than parliamentary regimes: slower output growth, higher and more volatile inflation and greater income inequality. Moreover, the magnitude of the effect is sizable. For example, annual output growth is between 0.6 and 1.2 percentage points lower and inflation is estimated to be at least four percentage points higher under presidential regimes relative to those under parliamentary ones. The difference in distributional outcomes is even starker; income inequality is 12 to $24 \%$ worse under presidential systems.
\end{abstract}

Keywords Constitutional economics · Form of government $\cdot$ Economic growth · Inflation $\cdot$ Income inequality

JEL classification $\quad \mathrm{E} 02 \cdot \mathrm{H} 11 \cdot \mathrm{P} 16$

\section{Introduction}

The proliferation of independent nations following the demise of the Soviet Union in the early 1990s revitalized the debate on constitutional rules, in particular on the forms of government. ${ }^{1}$ In his seminal paper, Linz (1990) argued that presidential regimes-wherein the

\footnotetext{
1 The origins of the debate on the implications of the form of constitutions date back much earlier. Both Walter Bagehot and Woodrow Wilson wrote on the ideal forms of constitutional structure in 1867 and 1885 , respectively (see Elgie 2005). The readers of this journal will know that modern constitutional political economy originated in Buchanan and Tullock (1962).
}

Richard McManus

richard.mcmanus@canterbury.ac.uk

1 Christ Church Business School, Canterbury Christ Church University, Canterbury, UK

2 Department of Economics and Related Studies, University of York, York, UK 
president is the chief executive officer and is elected by popular vote-are less conducive to stable democracy than parliamentary regimes, pointing to the 'perils of presidentialism' on two grounds. ${ }^{2}$ First, in presidential systems both the president and the assembly compete for legitimacy, frequently leading to divided government, with serious implications for the stability of democratic systems. Second, presidential regimes are associated with significant rigidity owing to both the single person nature of the office and the fixed terms associated with it. In contrast, Mainwaring and Shugart (1997) assert that presidential regimes also have advantages that may counterbalance some of their handicaps. For example, it is argued that presidential systems offer greater choice to the electorate who cast votes both for the chief executive and the legislative assembly. In addition, it is suggested that a more direct link exists between the choices made at the ballot box and the electoral outcomes under presidentialism, in contrast to parliamentary systems in which coalition formation may weaken that link, reducing accountability under the latter. Hence, Mainwaring and Shugart (1997) conclude that presidential regimes perform better where presidents have weaker legislative powers and when the political party system is not overly fragmented.

The work of Persson and Tabellini (2003) (PT, hereafter) on the economic effects of constitutions has changed the direction of the debate, initiating a new literature on the implications of political institutions for economic outcomes. By exploring both the form of government and electoral rules on macroeconomic outcomes, PT uncovered well-defined relationships between presidential versus parliamentary regimes and the size and the composition of government spending, budget deficits, output per worker and total factor productivity. In particular, they find that presidential regimes are associated with smaller governments, lower welfare spending, lower productivity and more pronounced electoral cycles.

A substantial part of the ensuing research effort aimed toward a re-examination of the impact of constitutional rules - regarding both the type of regime (presidential versus parliamentary) and electoral systems (majoritarian versus proportional representation) - on the size of government and the composition of public spending. For example, Blume et al. (2009) find that having a presidential rather than a parliamentary regime has no statistically significant effect on either the size of the government, the scale of corruption, output per worker, or total factor productivity. ${ }^{3}$ In contrast, Gregorini and Longoni (2009), by incorporating a large set of political and demographic factors, confirm PT's finding of presidential regimes being associated with smaller governments. Similarly, by refining PT's measurements and methodology, Rockey (2012) re-establishes the negative and significant impact of presidential regimes on the size of government. Interestingly, and in line with Blume et al. (2009), Rockey (2012) shows that the relationship disappears when the sample is extended to contain the new democracies of the 1990s.

The purpose of this paper is to ask whether certain forms of government are associated with better macroeconomic performance, a topic that has received much less attention in the existing literature. Even though the size of government, the scale of corruption and the composition of public spending (as studied in the existing literature) are important dimensions of policy outcomes, those variables would not form the standard set of macroeconomic performance indicators. Two exceptions to the above-mentioned studies explore the role of constitutions on economic growth: while Gerring et al. (2009) find a negative role

\footnotetext{
${ }^{2}$ See Carey (2008) for a comparative analysis of presidential versus parliamentary government.

3 Blume et al. (2009) extend the PT sample by including 31 additional countries that held free elections in the 1990s.
} 
of presidentialism on GDP per capita, Knutsen (2009), in an extended sample, finds no relationship between the form of government and economic growth. ${ }^{4}$

In this paper we explore the role of regime type on output and the volatility of output, inflation and the volatility of inflation, examining links that largely are unexplored in the existing literature. ${ }^{5}$ In addition to those four indicators, we extend our analysis to the link between regime type and income inequality. The reasons for including income inequality in our analysis are twofold. First, the level of inequality is an important determinant of political and economic instability with major implications for macroeconomic performance, as widely documented (see, for example, Alesina and Perotti 1996; Campos and Nugent 2002). Second, a steady rise in income inequality has been observed almost universally, reaching record levels at present, which makes it crucial to understand its potential sources (OECD 2015). ${ }^{6}$

In order to systematically link macroeconomic outcomes to the form of government, we utilize an annual dataset for 119 countries over the 1950-2015 period and construct an extensive set of performance indicators. We then formally examine the implications of the government system on each of those outcomes. Our findings clearly point to compelling advantages of parliamentary systems. For example, we find that countries run by presidential regimes consistently exhibit slower output growth, higher and more volatile inflation as well as greater income inequality relative to those under parliamentary regimes. Importantly, we find that the differences between the outcomes under the two systems are sizable: for example, the gap between annual output growth under presidential regimes relative to parliamentary ones varies between 0.6 and 1.2 percentage points. Similarly, in countries run by presidential systems inflation is estimated to be at least four percentage points higher than in those under parliamentary regimes. The difference in distributional outcomes is even starker; the distribution of income is between 12 and $24 \%$ more unequal under presidential systems.

A common concern in analyses of the link between institutional structure-including the form of government-and economic outcomes is the potential endogeneity of institutions. For example, it may be the case that constitutional forms are determined by economic conditions, such that the causal direction of the relationship between the government system and economic outcomes will not be straightforward. In light of such widely acknowledged endogeneity concerns, we subject our results to a battery of robustness checks as well as a number of remedial actions including instrumental variables estimation and the Heckman correction procedure. We show that our main findings regarding the role of the form of government on economic performance remain intact in a wide range of alternative specifications.

\footnotetext{
4 John Carey also related economic outcomes to constitutional regimes, although less formally, in his keynote address to the Conference on Coalitional Presidentialism at St Antony's College, Oxford, on May 2, 2014. In his analysis, Carey inspects a set of outcomes such as wealth, economic inequality, poverty mitigation, corruption, the homicide rate, rule of law and accountability across presidential versus other regimes.

5 Indeed, the basis of the loss function widely utilized in the policy games literature is the policymaker's aversion to high and volatile inflation as well as to low and volatile output. See, for example, Barro and Gordon (1983), among many others. More recently, Woodford (2003) shows that such a framework is a good approximation for policymaking in much richer models with microfoundations.

6 It is now believed widely that the substantial deterioration in income inequality was a key factor in a number of recent electoral surprises, including the United Kingdom's referendum in June 2016 to leave the European Union, the presidential elections in the United States in November 2016, as well as the recent parliamentary elections in the United Kingdom in June 2017 (see, for example, Bell and Machin 2016).
} 
What are the policy implications of examining the role of government systems on economic performance? Although constitutions remain in place for long periods of time, countries periodically consider constitutional amendments, including changes in the system of governance. Indeed, Hayo and Voigt (2010) identify 123 changes in the form of government in 169 countries from 1950 to 2003. Their evidence includes ten post-Soviet Union countries moving from presidential to parliamentary systems in the 1990s as well as ten countries in North Africa and Middle East that switched their regimes in the opposite direction. More recently, France has made changes to its constitution in the direction of a parliamentary system (see, for example, Rogoff 2011). Similarly, constitutional reform has been on the agenda in a number of countries in the Middle East since the widespread protests, referred to as the Arab Spring, starting in 2011. Also, at present, Turkey is in transition from its current parliamentary system into a presidential one, following a referendum in April 2017, while widespread protests have arisen in Venezuela and Poland recently over proposed constitutional changes. We believe that establishing the link between forms of government and economic outcomes serves a significant purpose by providing an important piece of information for constitutional framers in countries considering regime changes.

The rest of the paper is organized as follows. Section 2 presents the methodology, the data and descriptive statistics. Our formal empirical results are presented and examined in Sect. 3, which also contains our treatment of potential endogeneity issues, along with some additional robustness checks. Finally, Sect. 4 concludes.

\section{Estimation strategy and data}

\subsection{Methodology}

To assess the role of the form of government on macroeconomic performance, we estimate the following cross-country panel regressions:

$$
Y_{i, t}=\alpha+\theta \operatorname{Pres}_{i, t}+\gamma \operatorname{Maj}_{i, t}+\beta X_{i, t}+z_{i, t},
$$

where $Y_{i, t}$ represents the dependent variable of interest (levels and volatility of economic growth and inflation, as well as income inequality) in country $i$ in period $t, \operatorname{Pres}_{i, t}$ and Maj $_{i, t}$ are measures representing the form of government and voting rule, respectively, and $X_{i, \mathrm{t}}$ are a set of control variables, specific to the dependent variable in each case. Although our focus is on the form of government, it has been shown that voting rules also matter for economic outcomes; as such, we include variables for both types of constitutional rules (see, for example, PT; Blume et al. 2009; Rockey 2012).

We estimate regressions of specification (1) using generalized least squares with random effects and time dummies for each period. As a benchmark, we utilize 15-year horizons for each panel (as is common in the literature), starting from 1965, thus providing three (unbalanced) panels for each country in the regression. ${ }^{7}$ For each regression, three specifications are estimated incorporating three alternative sets of control variables in $X_{i, t}$ : first, a regression with no control variables; second, a specification with a limited number of control variables and, third, one with an extended set of regressors. As collinearity exists

\footnotetext{
7 Starting the time horizons in 1965 maximizes the number of observations with 15 -year panels. Sensitivity to that starting date is examined.
} 
between the form of government and other independent variables entered into the regressions, this sequential process will aid further understanding of the results.

\subsection{Data and constitutional variables}

We use data from a variety of empirical sources as discussed in "Appendix 1", which provides a full description of all variables; where available, all data are collected over the 1950-2015 period. We utilize two data sources for our measures of the form of government, each employing subtly different definitions. The first is from Bormann and Golder (2013) (BG, hereafter), who define presidential systems as those wherein the head of state cannot be removed by the elected assembly, as proposed by Cheibub et al. (2010). In addition, a country wherein a popularly elected president can be removed by the assembly is classified as operating in a 'semi-presidential' regime. All other regimes are parliamentary. PT follow a similar methodology, classifying a parliamentary government as one that can be subject to a confidence vote; correspondingly, a system for which a confidence vote is lacking is defined as a presidential government. ${ }^{8}$ Table 1 illustrates the countries categorized into each form of government by the two data sources; as is observed from the table, the only differences between the two sources are with respect to the 'semi-presidential' classification and the data coverage. The underlying classification of regimes into presidential, semi-presidential and parliamentary regimes also is presented geographically in Fig. 3 in the "Appendix 1".

\subsection{Descriptive statistics}

Table 2 presents the full sample means for each of the five dependent variables in our analysis, under presidential and parliamentary systems, based on both the BG and PT classifications. As can be seen, in a great majority of the cases average macroeconomic outcomes are more favorable under parliamentary regimes relative to those under presidential ones, and the differences between the two systems frequently are statistically significant. Using the lower end of our estimates, on average, parliamentary countries grow 0.7 percentage points per annum faster than the presidential ones; have 4.6 percentage points lower inflation; have smaller variations in inflation; and have less income inequality. ${ }^{9}$ As is also clear from Table 2, the disparities in macroeconomic outcomes are larger and more statistically significant when using the PT definition of forms of government; those differences stem from PT's smaller sample and are not explained by differences in country classifications between the two presidential variables.

Figure 1 presents histograms for our five performance indicators under both parliamentary and presidential regimes. It is observed that for every macroeconomic outcome, with the exception of growth volatility, the better performance of parliamentary regimes relative to presidential ones is consistent throughout the sample and is not driven by outliers.

Figure 2 presents scatter plots for countries along the metrics for which the differences reported in Table 2 are statistically significant. In each plot, a point represents a country and solid lines illustrate the median value for each of the macroeconomic outcomes. In the

\footnotetext{
${ }^{8}$ PT discuss two dimensions across which they see presidential systems being defined: that of the confidence vote and that of the separation of powers between the president and the legislature.

9 To remove the impact of inflation outliers, we use the method applied in Cukierman et al. (1992), wherein the GDP deflator, $\pi$, is transformed using $\pi /(1+\pi)$.
} 


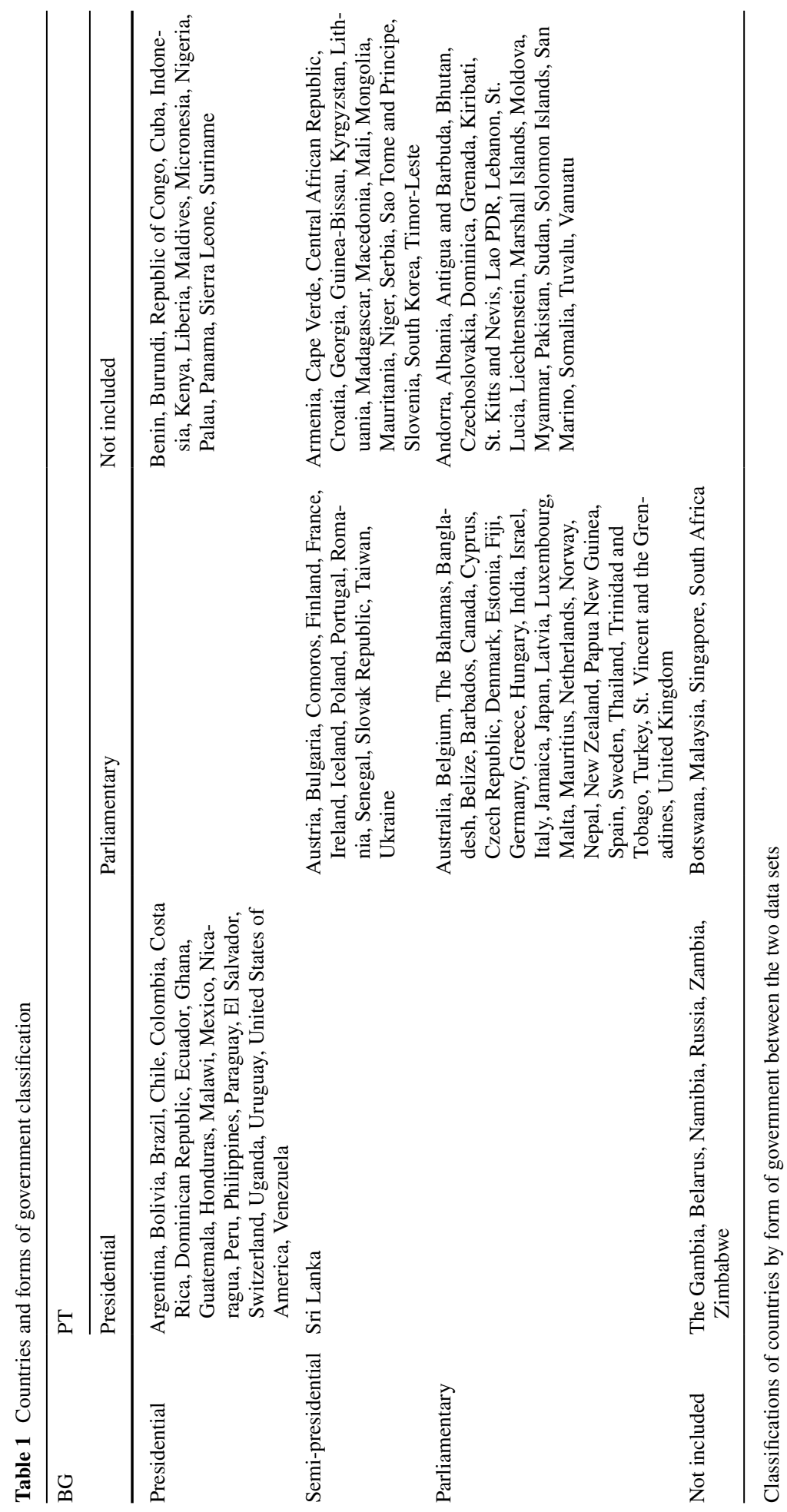


Table 2 Presidential and parliamentary regimes: descriptive statistics

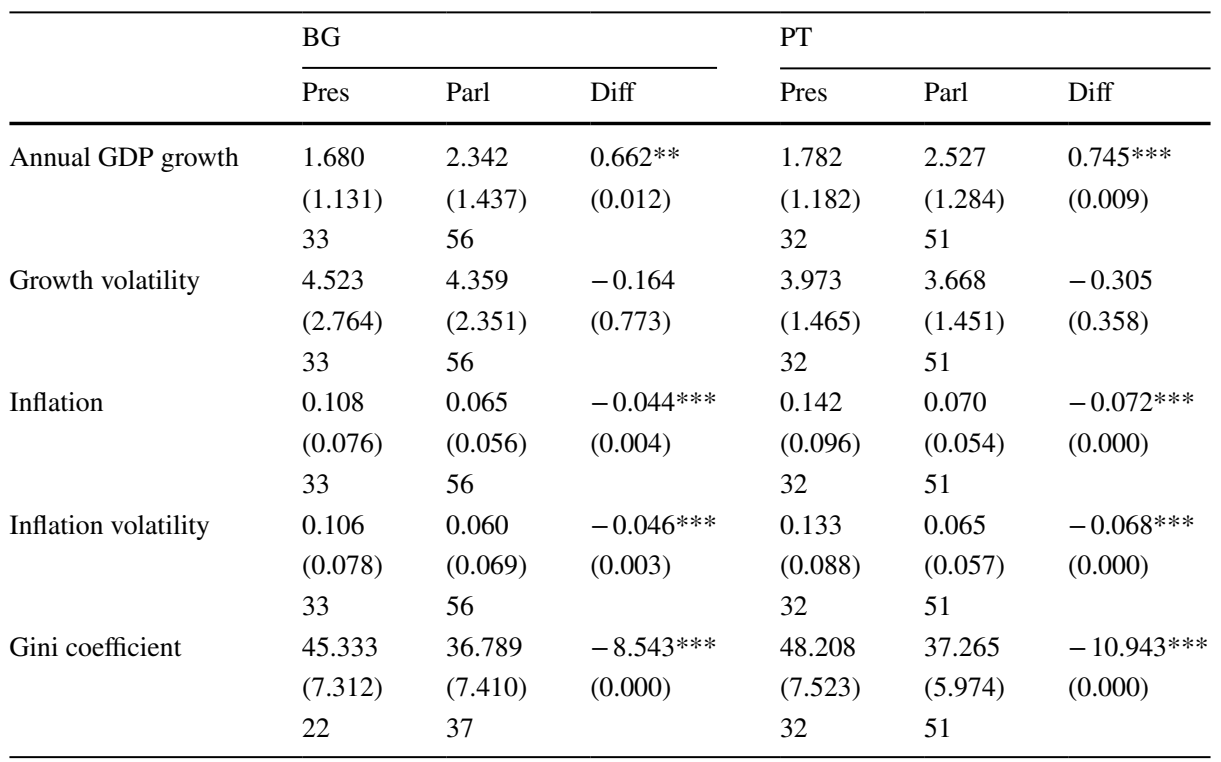

Descriptive statistics based on whole sample averages. For each of the five variables represented in the first column, the mean is calculated under both presidential ('Pres') and parliamentary ('Parl') regimes, with both the standard deviation (in parentheses) and number of observations presented underneath. In the fourth and seventh columns the difference between these two means are presented, with $p$ values from t-tests presented underneath (in parentheses). A standard star convention is used, with *, ** and *** representing significance levels of 10,5 and $1 \%$ respectively. Both BG and PT are used in classifying presidential versus parliamentary regimes; in the case of the former, semi-presidential systems are not included in the analysis
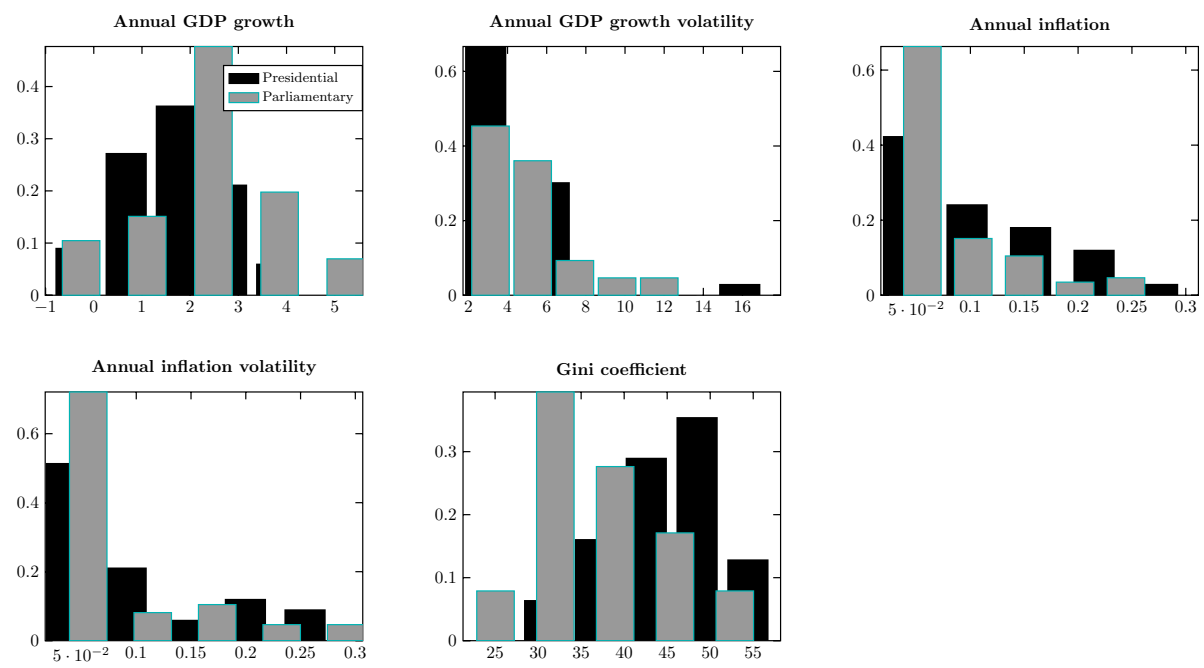

Fig. 1 Presidential and parliamentary regimes: macroeconomic outcomes. Histograms illustrating the distribution of our macroeconomic indicators of interest as an average over the whole sample (1950-2015) across parliamentary and presidential regimes using BG classification for government structures 

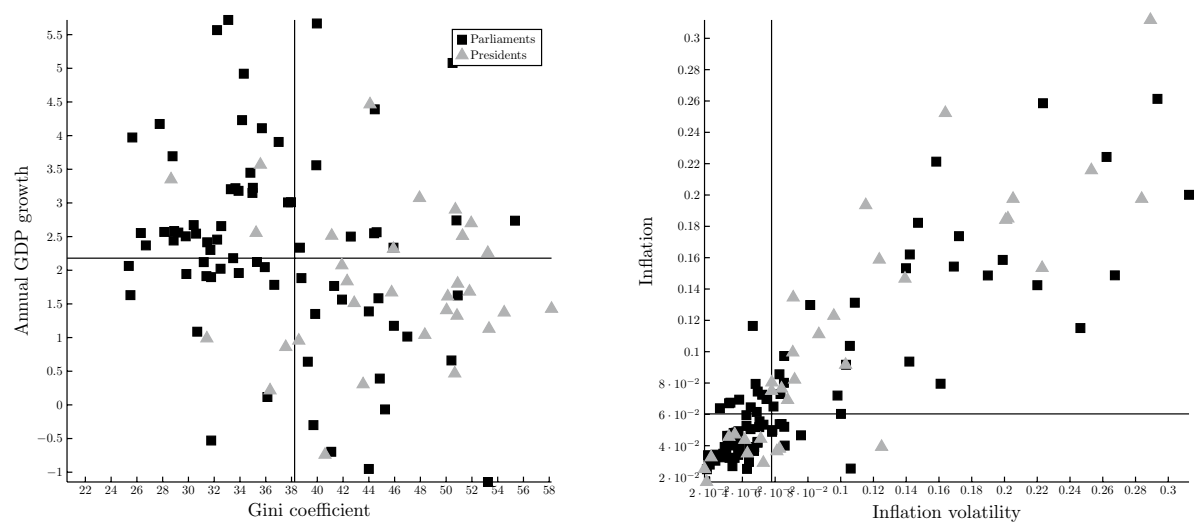

Fig. 2 Presidential and parliamentary regimes: macroeconomic outcomes. Scatter plots illustrating specific country outcomes across our macroeconomic indicators of interest as an average over the whole sample (1950-2015) for parliamentary and presidential regimes using BG classification for government structures. The solid lines in each plot represent median outcomes for each metric across all countries

left-hand panel of Fig. 2 the top-left quadrant represents those countries of above-average economic growth and below-average income inequality. In this good-outcomes quadrant, $91 \%$ of countries are parliamentary, representing half of all parliamentary countries. In the bottom-right quadrant, representing worse than average outcomes for economic growth and inequality, $61 \%$ are presidential countries, representing half of all presidential countries.

Similar results are found in the right-hand panel wherein the best outcomes are those found in the bottom-left quadrant, namely, below-average levels and volatilities of inflation. In that quadrant $80 \%$ are parliamentary countries (nearly half of all parliamentary countries), whereas in the opposing top-right quadrant $48 \%$ of observations are from presidential countries (representing $63 \%$ of all presidential countries).

\section{Forms of government and macroeconomic outcomes}

In this section, we present and discuss the effects of the government systems on five separate outcome measures, as set out above. They are each taken in turn and are based on empirical results from estimating specification (1).

\subsection{Endogeneity concerns}

An important issue in identifying the effects of constitutional rules on macroeconomic outcomes is related to the potential endogeneity of political institutions. The concern is that economic conditions could influence the choice of constitutional forms and, thus, the causal direction of outcomes is not straightforward. Such endogeneity issues arise from two main sources: first, the limited in-country variation between forms of government means that statistical inference is based on cross-country analysis; second, any decision on the form of government is unlikely to be truly exogenous to the political and economic 
climate of the country. ${ }^{10}$ Applying ordinary least squares estimation relies on conditional independence, that is, the selection of the form of government is assumed to be random after controlling for all other variables $[X$ in (1)]. Following PT, we take two remedial actions: instrumental variables estimation and the Heckman correction procedure.

\subsubsection{Instrumental variables}

The most widely used strategy in the face of potential endogeneity concerns is instrumental variables. In that approach, the bias caused by the selection of the form of government in a given country being non-random is first estimated prior to estimating the size of the coefficient $\theta$ in (1). We follow PT in selecting our set of instruments: variables indicating the time when a country's current constitutional form was adopted (using dummy variables for periods before 1920, between 1921 and 1950, between 1951 and 1980, and beyond 1981); the age of democracy within a given country (measured as the length of time in which the Polity database score of a country consecutively has been positive); language variables representing Western influences in the country; and the country's latitude. ${ }^{11}$ Furthermore, similar to PT and Rockey (2012) we apply the same instruments for the Heckman correction procedure, explained below.

Acemoglu (2005) argues that the chosen variables make for weak instruments, as the constitutional timing variables have limited statistical significance and the main determinants are the Hall and Jones (1999) variables of language and latitude, variables that Acemoglu (2005) argues are not convincing instruments for constitutional features. Rockey (2012) refines the constitutional timing variables to gain more explanatory power for the form of government in two ways: one set of variables are for when a country genuinely holds a democratic election within a given constitutional framework (and not just when the constitution becomes law), and a second set of dummy variables indicating when a country's constitution is promulgated. Rockey (2012) demonstrates that those factors provide better instruments for the form of government.

Our approach is to consider three separate sets of instruments, using the constitutional timing dummies as in PT, as well as the two sets of timing dummies from Rockey (2012); all sets of instruments also include the age of democracy, language variables and the country's latitude. Table 3 reports results from first-stage estimates using those three sets of instruments. All have significant explanatory power, with first stage F-tests in excess of 30, and even when only the constitutional variables are considered, values of over ten typically are present.

Our strategy throughout the paper is to present results from a panel regression applying generalized least squares and, subsequently, similar estimates from applying both instrumental variables and the Heckman correction procedure. For the latter two, our benchmark instruments will be the constitutional timing variables from PT, as they provide the most consistent performances from the first-stage regressions for both institutional timing and

\footnotetext{
10 On the other hand, evidence on the insignificant influences of economic variables on the form of government comes from Hayo and Voigt (2010), who present a comprehensive analysis of the sources of constitutional changes. They find that changes in the form of government-in either direction-are influenced by political factors, such as the characteristics of the political system, political leaders and political conflict, but not economic and sociodemographic factors.

11 A full list and definitions of the variables in our analysis can be found in "Appendix 1".
} 


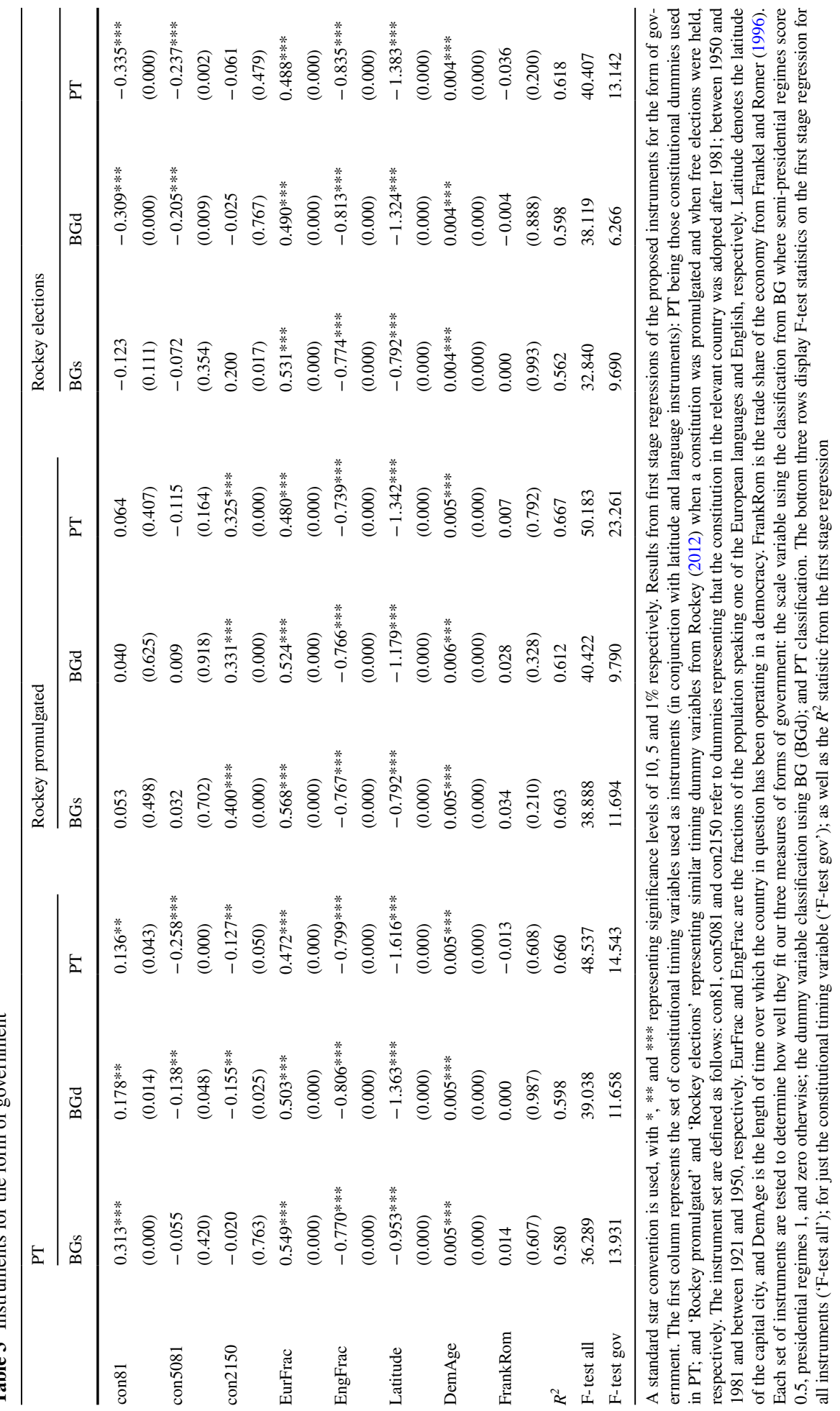


Hall and Jones's (1999) variables. Our models are estimated on all sets of instruments to ensure that the results are robust.

\subsubsection{Heckman correction estimation}

Another strategy in testing for possible endogenous relationships in the causal direction, as is also utilized by PT, is the Heckman correction procedure. With that method, a potential selection bias in the observations that are utilized in the regression analysis is controlled for by adjusting estimates for a possible correlation between the random elements in macroeconomic outcomes and the selection of constitutional provisions. In the first stage of a Heckman correction, a probit regression is estimated on constitutional selection. Similar to PT, we enter dummy variables for the date on which the country's constitution was established, the age of democracy, 'cultural influences' on the population (the proportion of people who speak English or another European language), and the country's latitude.

\subsection{Economic growth and volatility}

Table 4 presents panel regression results estimating the impact of the form of government on rates of annual GDP growth, utilizing generalized least squares with random effects. We incorporate standard control variables in line with Barro (2007). For each regression specification, three separate measures are entered to represent the form of government: a tripartite variable set equal to 0.5 for countries classified in BG as semi-presidential, 1 if presidential, and 0 if parliamentary; a second specification using the 'semi-presidential' and 'presidential' classifications from BG as dummy variables; and a similar specification using the data from PT, as discussed in Sect. 2.2.

The relevant control variables comprise InitialGDP, which represents the natural logarithm of a country's GDP per capita; Education, measured by the log of the average number of years of the population's educational attainment; Fertility and LifeExp, measured by the log of the number of births per woman and life expectancy measured at birth, respectively; GovtSize, defined as the ratio of total government spending to GDP; and ExRateVol, measured as the standard deviation of the nominal exchange rate between the domestic currency and the US dollar. The first four of those variables are measured at the start of the panel period, whereas the final two are taken as averages over the full sample. Table 4 presents estimation results from three sets of empirical specifications: one with no control variables; one for a benchmark specification wherein the control variables are composed of InitialGDP and Education; and an extended set incorporating all further control variables.

The estimation results in Table 4 point to a clear association between constitutional rules and economic growth: the average growth rate of GDP is slower under presidential regimes by between 0.6 and 1.2 percentage points (consistent with the results from Table 2 and the top left-hand panel in Fig. 1); the effect is statistically significant at the $1 \%$ level in the six specifications with no and less than a full set of control variables, and at $5 \%$ when additional controls are entered. Note that at low levels of initial income, Table 4 suggests that presidential countries will grow faster, consistent with the convergence hypothesis; that is, lower (initial) GDP per capita is associated with faster growth rates such that poorer countries catch up with richer ones. Indeed, if estimations are performed on regressions similar to those in Table 4 without controlling for initial GDP, statistically insignificant 


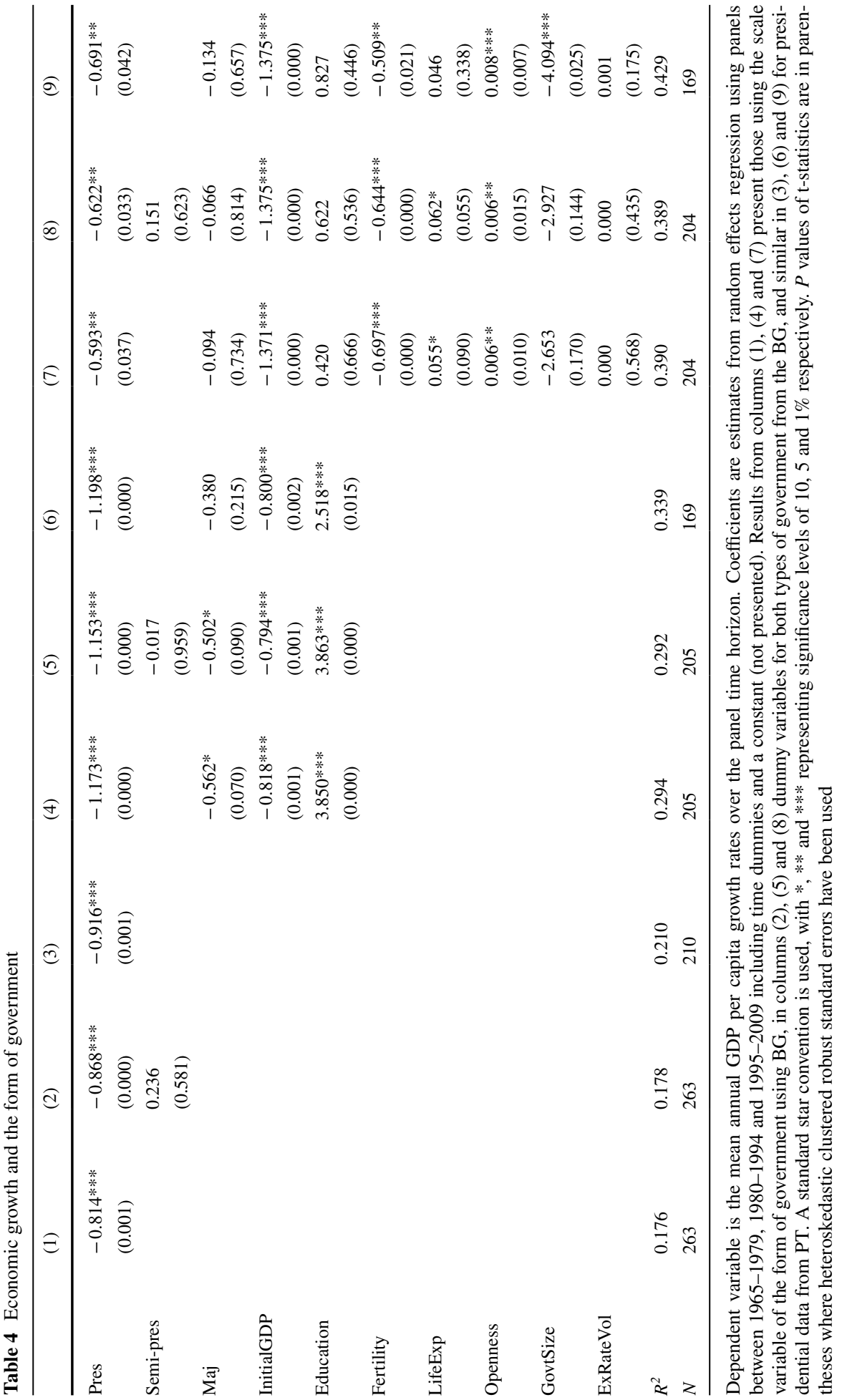


coefficients are attached to the form of government variable in columns (7)-(9). ${ }^{12}$ Presidential regimes are associated with lower levels of education, life expectancy, trade openness and higher fertility rates (with statistically significant correlation coefficients), all of which are also associated with slower economic growth. Collinearity explains why the estimated coefficients attached to the form of government variable become smaller in Table 4 in specifications (7)-(9) than in specifications (3)-(6), along with why statistical significance declines. The results from Table 4 support the convergence hypothesis: conditional on the level of initial GDP per capita: countries with presidential regimes grow slower than those with parliamentary ones. ${ }^{13}$

Table 5 presents results from estimating the effect of the form of government on economic growth using instrumental variables and Heckman correction techniques, as discussed in Sect. 3.1. For all nine specifications, the sizes of the estimated coefficients of interest increase for both the instrumental variable and Heckman correction techniques. Furthermore, the coefficients are estimated more precisely and are statistically significant. Presidential regimes exhibit slower economic growth, all else equal.

We repeat the same exercise to examine the impact of regime type on growth volatility, defined as standard deviations in the rates of annual output growth. The control variables entered into this specification are the same as those above, with additional variables measuring democracy (Polity) taken from the Polity IV database, and the volatility of trade openness (Open $\mathrm{Vol}$ ). As can be seen from Table 6, no statistically significant association between regime type and the volatility of economic growth emerges in our regressions; these results reconcile with those from Table 2. The same holds true for the electoral system, except in two specifications, wherein majoritarian electoral regimes are estimated to result in less output volatility. When performing comparable analysis as in Table 6 using instrumental variables and the Heckman correction, similar results prevail: a statistically insignificant relationship between the form of government and output growth volatility is estimated (not reported).

\subsection{Inflation and its volatility}

We now turn to the potential influence of the form of government on inflation performance (its rate and volatility). We estimate the specification in (1) wherein the dependent variable is the mean of the transformed GDP deflator. The GDP deflator, $\pi$, obtained from the World Bank, is transformed using $\pi /(1+\pi)$ to remove the impact of high inflation outliers (as identified in Cukierman et al. 1992): entering the raw inflation figures would weight unduly a few outliers of very high inflation rates. In line with the existing empirical work on inflation, the specifications share common control variables InitialGDP, Openness and ExRateVol. In addition to those controls, we enter a measure first proposed and developed by Cukierman et al. (1992) of central bank independence (CBI), for which more

\footnotetext{
12 More generally, suppose that a dependent variable $\left(Y_{t}\right)$ is a function of two independent variables $\left(X_{1, t}\right.$ and $\left.X_{2, t}\right)$ such that $Y_{t}=\alpha+\beta_{1} X_{1, t}+\beta_{2} X_{2, t}+\varepsilon_{t}$ is estimated; and $X_{2, t}$ also is a function of $X_{1, t}$ such that $X_{2, t}=\lambda+\gamma X_{1, t}+e_{t}$. Substituting the second specification into the first one yields $Y_{t}=\left[\alpha+\beta_{2} \lambda\right]+X_{1, t}$ $\left[\beta_{1}+\beta_{2} \gamma\right]+\left[\beta_{2} X_{2, t} e_{t}+\varepsilon_{t}\right]$. It therefore follows that the impact of $X_{1, t}$ on $Y_{t}$ is both direct (estimated through $\beta_{1}$ ) and indirect (through the effect $X_{1, t}$ has on $X_{2, t}$ ). If $Y$ is economic growth, $X_{1}$ our measure of the form of government and $X_{2}$ (initial GDP), where $\beta_{1}<0, \beta_{2}<0$ and $\gamma<0$, then the total estimated impact of presidential regimes on economic growth is smaller than the direct effect.

13 Similarly, PT find that presidential regimes have smaller governments. If regressions are estimated dropping GovtSize, we find quantitatively similar results.
} 


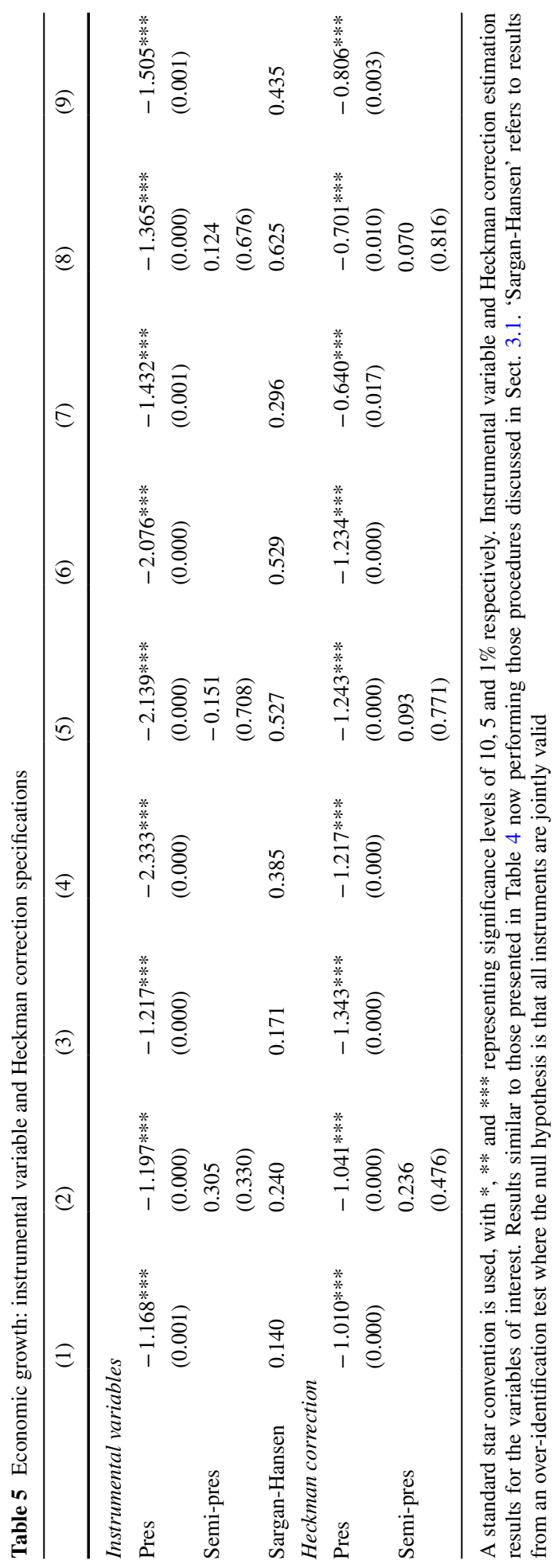


Table 6 Volatility of economic growth and the form of government

\begin{tabular}{|c|c|c|c|c|c|c|c|c|c|}
\hline & (1) & (2) & (3) & (4) & (5) & (6) & (7) & (8) & (9) \\
\hline Pres & $\begin{array}{l}0.294 \\
(0.409)\end{array}$ & $\begin{array}{l}0.252 \\
(0.475)\end{array}$ & $\begin{array}{l}0.165 \\
(0.584)\end{array}$ & $\begin{array}{l}-0.079 \\
(0.837)\end{array}$ & $\begin{array}{l}-0.052 \\
(0.893)\end{array}$ & $\begin{array}{l}-0.246 \\
(0.498)\end{array}$ & $\begin{array}{l}-0.079 \\
(0.823)\end{array}$ & $\begin{array}{l}-0.059 \\
(0.868)\end{array}$ & $\begin{array}{l}-0.359 \\
(0.318)\end{array}$ \\
\hline $\begin{array}{r}\text { Semi- } \\
\text { pres }\end{array}$ & & $\begin{array}{l}0.724^{*} \\
(0.076)\end{array}$ & & & $\begin{array}{l}0.415 \\
(0.354)\end{array}$ & & & $\begin{array}{l}0.475 \\
(0.239)\end{array}$ & \\
\hline Maj & & & & $\begin{array}{l}-0.307 \\
(0.433)\end{array}$ & $\begin{array}{l}-0.245 \\
(0.520)\end{array}$ & $\begin{array}{l}-0.568 * * \\
(0.015)\end{array}$ & $\begin{array}{l}-0.302 \\
(0.413)\end{array}$ & $\begin{array}{l}-0.236 \\
(0.519)\end{array}$ & $\begin{array}{l}-0.614^{* *} \\
(0.010)\end{array}$ \\
\hline $\begin{array}{r}\text { Initial- } \\
\text { GDP }\end{array}$ & & & & $\begin{array}{l}-0.137 \\
(0.356)\end{array}$ & $\begin{array}{l}-0.103 \\
(0.467)\end{array}$ & $\begin{array}{l}-0.196 \\
(0.211)\end{array}$ & $\begin{array}{l}-0.037 \\
(0.830)\end{array}$ & $\begin{array}{l}-0.001 \\
(0.996)\end{array}$ & $\begin{array}{l}-0.172 \\
(0.329)\end{array}$ \\
\hline $\begin{array}{r}\text { Open- } \\
\text { ness }\end{array}$ & & & & $\begin{array}{l}0.013^{* *} \\
(0.047)\end{array}$ & $\begin{array}{l}0.013 * \\
(0.057)\end{array}$ & $\begin{array}{l}0.008^{* *} \\
(0.033)\end{array}$ & $\begin{array}{l}0.001 \\
(0.875)\end{array}$ & $\begin{array}{l}0.000 \\
(0.964)\end{array}$ & $\begin{array}{l}0.002 \\
(0.715)\end{array}$ \\
\hline Polity & & & & $\begin{array}{l}-0.145^{* * *} \\
(0.000)\end{array}$ & $\begin{array}{l}-0.144 * * * \\
(0.000)\end{array}$ & $\begin{array}{l}-0.105^{* * *} \\
(0.000)\end{array}$ & $\begin{array}{l}-0.129 * * * \\
(0.000)\end{array}$ & $\begin{array}{l}-0.127 * * * \\
(0.000)\end{array}$ & $\begin{array}{l}-0.105^{* * *} \\
(0.000)\end{array}$ \\
\hline $\begin{array}{l}\text { Open- } \\
\text { Vol }\end{array}$ & & & & & & & $\begin{array}{l}0.086 * * * \\
(0.003)\end{array}$ & $\begin{array}{l}0.088^{* * *} * \\
(0.002)\end{array}$ & $\begin{array}{l}0.046 * \\
(0.089)\end{array}$ \\
\hline $\begin{array}{c}\text { Govt- } \\
\text { Size }\end{array}$ & & & & & & & $\begin{array}{l}2.369 \\
(0.312)\end{array}$ & $\begin{array}{l}2.139 \\
(0.345)\end{array}$ & $\begin{array}{l}-0.411 \\
(0.847)\end{array}$ \\
\hline $\begin{array}{r}\text { ExRat- } \\
\text { eVol }\end{array}$ & & & & & & & $\begin{array}{l}0.000 \\
(0.679)\end{array}$ & $\begin{array}{l}0.000 \\
(0.644)\end{array}$ & $\begin{array}{l}0.000 \\
(0.752)\end{array}$ \\
\hline$R^{2}$ & 0.096 & 0.096 & 0.055 & 0.161 & 0.159 & 0.145 & 0.168 & 0.170 & 0.173 \\
\hline$n$ & 281 & 281 & 251 & 246 & 246 & 194 & 246 & 246 & 194 \\
\hline
\end{tabular}

A standard star convention is used, with *, ** and *** representing significance levels of 10,5 and $1 \%$ respectively. Dependent variable is the standard deviation in annual growth rates of GDP per capita over the panel time horizon; all else is as defined earlier

independence is anticipated to lead to more favorable inflation outcomes. That variable is reserved for the extended regression specification owing to data availability.

Consistent with our earlier results, presidential regimes are associated with inferior outcomes: countries governed by presidential systems experience inflation rates that are on average more than four percentage points higher than for those governed by parliamentary regimes. ${ }^{14}$ That effect is consistent across all specifications and is larger when the measure of central bank independence is entered. The significances of the coefficients attached to the form of government variable are weakened by the electoral rule, the latter being found to be more consistently and strongly statistically significant. Countries with majoritarian electoral rules are estimated to achieve lower inflation rates, by between six and nine percentage points, than those with proportional representation. The weakening of the formof-government results originates in considerable collinearity: parliamentary countries are more likely than presidential ones to adopt majoritarian voting systems. Similarly, as discussed in Sect. 3.2, presidential regimes and initial GDP are correlated negatively. Estimating the specifications by dropping InitialGDP leads to larger and more statistically significant detrimental effects of presidential regimes.

\footnotetext{
${ }^{14}$ Note that in order to convert point estimates for the marginal impact of the form of government ( $x$ say) on the transformed variable for inflation, where $y=\pi /(1+\pi)$, one must use the chain rule to get $\partial \pi / \partial x=\partial \pi /$ $\partial y \times \partial y / \partial x=\beta /(1-y)^{2}$, where $\beta$ is the coefficient from the regression and where the mean of $y$ (i.e., 0.0924) is applied.
} 


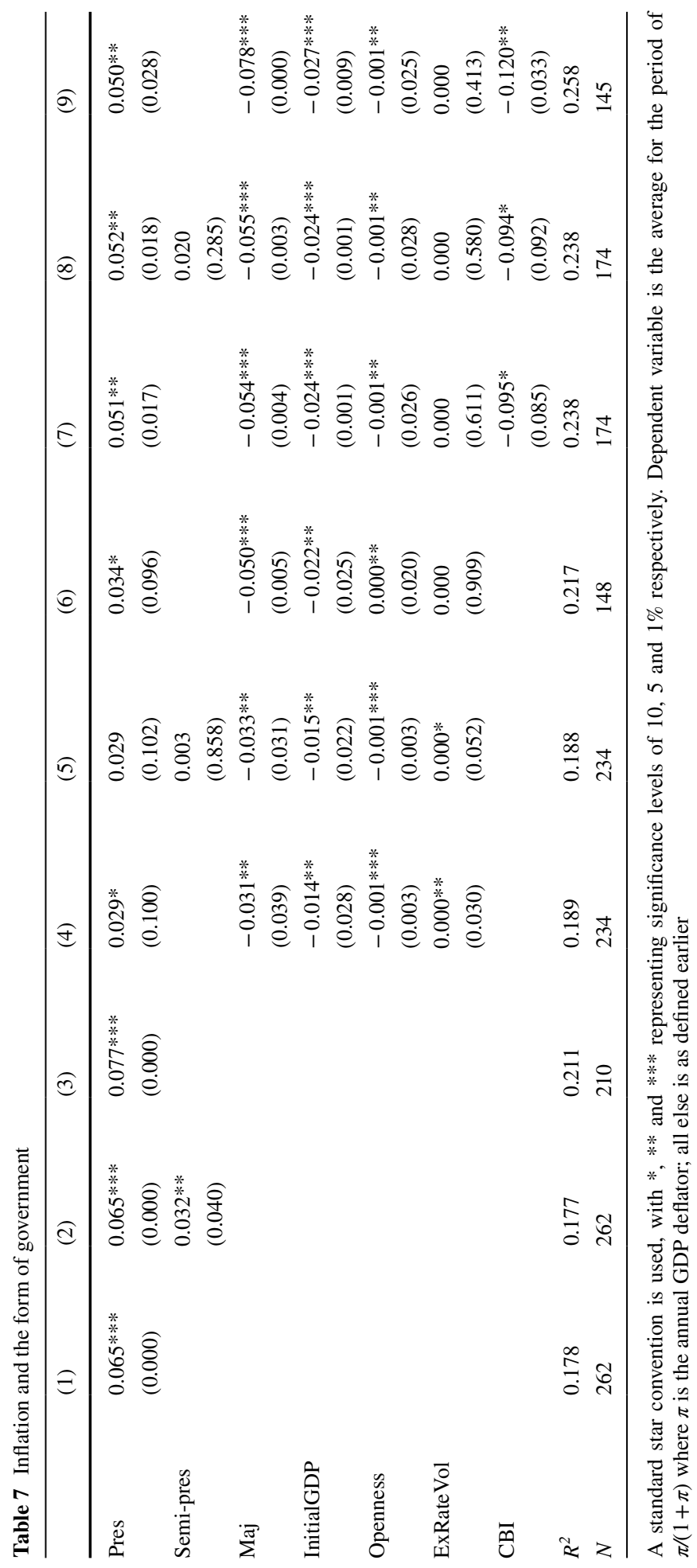


Table 8 Inflation: instrumental variable and Heckman correction specifications

\begin{tabular}{|c|c|c|c|c|c|c|c|c|c|}
\hline & (1) & (2) & (3) & (4) & (5) & (6) & (7) & (8) & (9) \\
\hline \multicolumn{10}{|c|}{ Instrumental variables } \\
\hline Pres & $\begin{array}{l}0.132 * * * \\
(0.000)\end{array}$ & $\begin{array}{l}0.131 * * * \\
(0.000)\end{array}$ & $\begin{array}{l}0.090^{* * * *} \\
(0.000)\end{array}$ & $\begin{array}{l}0.043 \\
(0.130)\end{array}$ & $\begin{array}{l}0.041 \\
(0.158)\end{array}$ & $\begin{array}{l}0.041 \\
(0.164)\end{array}$ & $\begin{array}{l}0.075^{* *} \\
(0.026)\end{array}$ & $\begin{array}{l}0.071 \text { *** } \\
(0.037)\end{array}$ & $\begin{array}{l}0.063 * * \\
(0.031)\end{array}$ \\
\hline Semi-pres & & $\begin{array}{l}0.062 * \\
(0.055)\end{array}$ & & & $\begin{array}{l}0.011 \\
(0.701)\end{array}$ & & & $\begin{array}{l}0.024 \\
(0.392)\end{array}$ & \\
\hline $\begin{array}{l}\text { Sargan- } \\
\text { Hansen }\end{array}$ & 0.508 & 0.501 & 0.254 & 0.107 & 0.101 & 0.121 & 0.248 & 0.276 & 0.106 \\
\hline \multicolumn{10}{|c|}{ Heckman correction } \\
\hline Pres & $\begin{array}{l}0.050^{* * * *} \\
(0.002)\end{array}$ & $\begin{array}{l}0.053^{* * * *} \\
(0.001)\end{array}$ & $\begin{array}{l}0.055^{* * * *} \\
(0.000)\end{array}$ & $\begin{array}{l}0.029 * * * \\
(0.070)\end{array}$ & $\begin{array}{l}0.030^{*} \\
(0.051)\end{array}$ & $\begin{array}{l}0.022 * \\
(0.064)\end{array}$ & $\begin{array}{l}0.054 * * * \\
(0.006)\end{array}$ & $\begin{array}{l}0.057^{* * *} \\
(0.001)\end{array}$ & $\begin{array}{l}0.031 \text { ** } \\
(0.034)\end{array}$ \\
\hline Semi-pres & & $\begin{array}{l}0.017 * * * \\
(0.007)\end{array}$ & & & $\begin{array}{l}0.000 \\
(0.987)\end{array}$ & & & $\begin{array}{l}0.008 \\
(0.381)\end{array}$ & \\
\hline
\end{tabular}

A standard star convention is used, with $*, * *$ and $* * *$ representing significance levels of 10,5 and $1 \%$ respectively. Instrumental variable and Heckman correction estimation results for the variables of interest. Results similar to those presented in Table 7 now performing those procedures outlined in Sect. 3.1

Table 8 presents results when instrumental variables and Heckman correction estimation techniques are applied. Similar to the results in Table 5, the point estimates with respect to the instrumental variable method increase; the coefficients are estimated with more precision and more statistical significance. ${ }^{15}$ The results from the Heckman correction procedure are in line with those from generalized least squares, although they are again estimated with more precision. In general, the results from Table 8 are consistent with (if not stronger than) those from Table 7.

Table 9 performs the same exercise for inflation volatility. Parallel to the findings above, inflation is more volatile under both presidential regimes and proportional electoral systems; however, whereas the results for the voting rule remain significant, those for the form of government are less consistently significant. This result, again, arises from the presence of collinearity between the form of government and the voting rule: when the regression is run without the latter, the former is statistically significant to at least $5 \%$ in all specifications. That is, the constitutional framework of a country and the volatility of inflation are correlated, and the voting rule explains inflation volatility better than the form of governance. ${ }^{16}$

Table 10 presents corresponding results using instrumental variables and Heckman correction estimation. Similar to above, point estimates are larger using those techniques, and are estimated with more precision, statistically significant at the $95 \%$ confidence level in all but two of the specifications. In sum, the evidence suggests that countries with presidential regimes have higher inflation rates and more volatility in those rates.

\footnotetext{
${ }^{15}$ Note that some of the increases in the sizes of these coefficients is explained by the smaller sample size owing to the availability of observations on the instruments (sample sizes are on average $24 \%$ smaller in Table 8 than in Table 7). When specifications using generalized least squares are run on this smaller sample, point estimates increase on average by $14 \%$; that is less than the increase in the instrumental variables approach, but accounts for some of the difference.

${ }^{16}$ Similarly, dropping InitialGDP from the specifications in Table 9 also returns larger point estimates for the effect of presidential regimes on the variability of inflation, all statistically significant at the $95 \%$ confidence level or higher.
} 


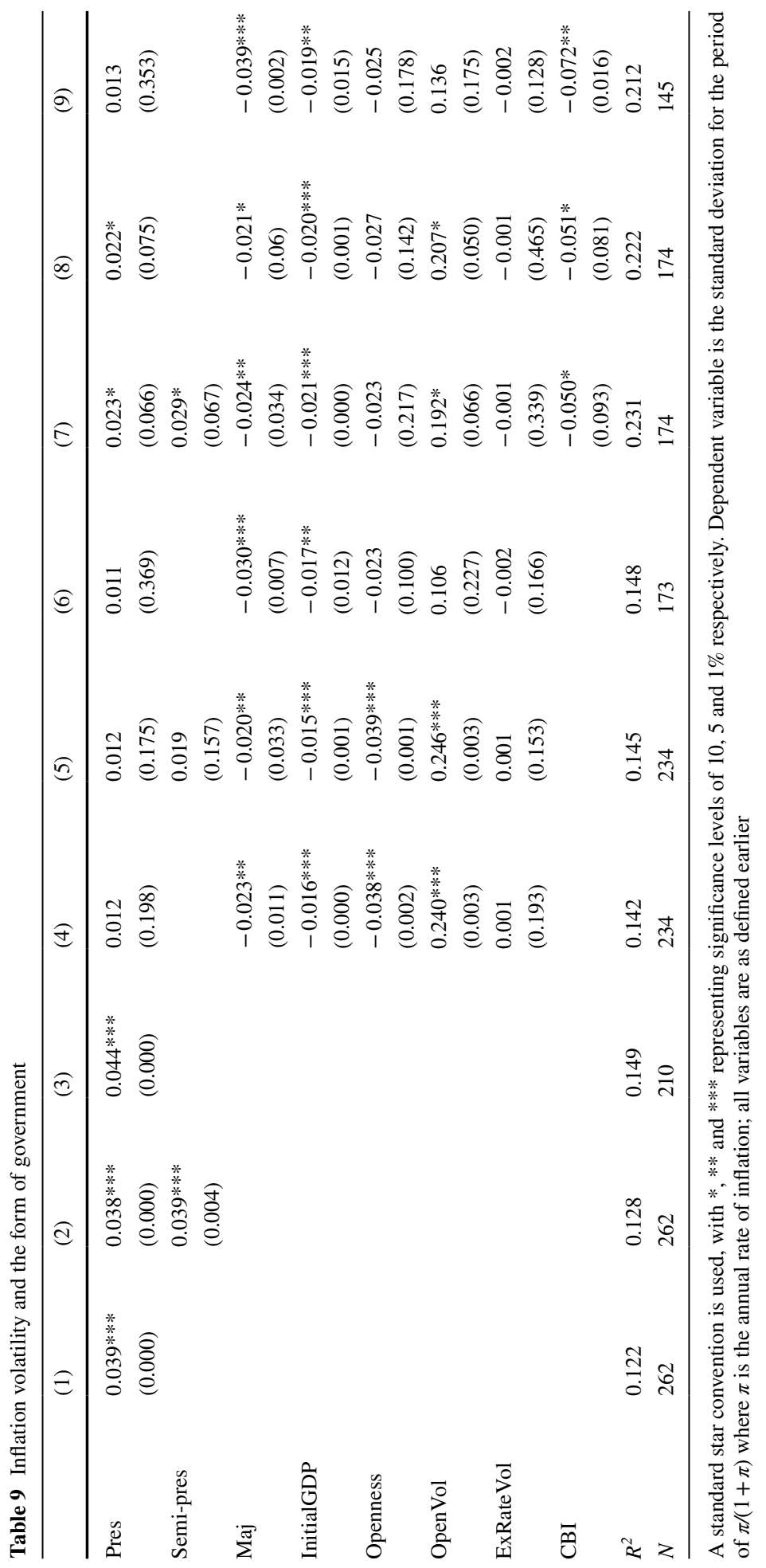


Table 10 Inflation volatility: instrumental variable and Heckman correction specifications

\begin{tabular}{|c|c|c|c|c|c|c|c|c|c|}
\hline & (1) & (2) & (3) & (4) & (5) & (6) & (7) & (8) & (9) \\
\hline \multicolumn{10}{|c|}{ Instrumental variables } \\
\hline Pres & $\begin{array}{l}0.072 * * * \\
(0.000)\end{array}$ & $\begin{array}{l}0.073 * * * \\
(0.000)\end{array}$ & $\begin{array}{l}0.048^{* * * *} \\
(0.000)\end{array}$ & $\begin{array}{l}0.043 * * \\
(0.017)\end{array}$ & $\begin{array}{l}0.047^{* * * *} \\
(0.006)\end{array}$ & $\begin{array}{l}0.026 \\
(0.133)\end{array}$ & $\begin{array}{l}0.056 * * * \\
(0.008)\end{array}$ & $\begin{array}{l}0.056 * * * \\
(0.005)\end{array}$ & $\begin{array}{l}0.028^{*} \\
(0.100)\end{array}$ \\
\hline Semi-pres & & $\begin{array}{l}0.043^{*} \\
(0.066)\end{array}$ & & & $\begin{array}{l}0.039 * \\
(0.080)\end{array}$ & & & $\begin{array}{l}0.037 * \\
(0.070)\end{array}$ & \\
\hline $\begin{array}{l}\text { Sargan- } \\
\text { Hansen }\end{array}$ & 0.134 & 0.138 & 0.150 & 0.376 & 0.407 & 0.141 & 0.345 & 0.364 & 0.137 \\
\hline \multicolumn{10}{|c|}{ Heckman correction } \\
\hline Pres & $\begin{array}{l}0.037 * * * \\
(0.000)\end{array}$ & $\begin{array}{l}0.038 * * * \\
(0.000)\end{array}$ & $\begin{array}{l}0.033^{* * * *} \\
(0.000)\end{array}$ & $\begin{array}{l}0.028^{* * * *} \\
(0.000)\end{array}$ & $\begin{array}{l}0.029 * * * \\
(0.000)\end{array}$ & $\begin{array}{l}0.021 * * \\
(0.012)\end{array}$ & $\begin{array}{l}0.050 * * * \\
(0.000)\end{array}$ & $\begin{array}{l}0.048 * * * \\
(0.000)\end{array}$ & $\begin{array}{l}0.025 * * * \\
(0.000)\end{array}$ \\
\hline Semi-pres & & $\begin{array}{l}0.012 \text { ** } \\
(0.130)\end{array}$ & & & $\begin{array}{l}0.013^{* * *} \\
(0.000)\end{array}$ & & & $\begin{array}{l}0.021 * * \\
(0.034)\end{array}$ & \\
\hline
\end{tabular}

A standard star convention is used, with $* * *$ and $* * *$ representing significance levels of 10,5 and $1 \%$ respectively. Instrumental variable and Heckman correction estimation results for the variables of interest. Results similar to those presented in Table 9 now performing those procedures outlined in Sect. 3.1

\subsection{Income inequality}

We next turn to the relationship between the form of government and income inequality, a topic of considerable contemporary concern. Income inequality is shown to be an important factor underlying both economic and political instability, with clear implications for overall macroeconomic performance (see, for example, Alesina and Perotti 1996, among others). When combined with steadily rising income inequality almost everywhere over the past three decades and its record levels at present (see, for example, OECD 2015), we argue that it is important to understand whether the form of government plays any role in distributive outcomes. To the best of our knowledge, our paper is the first to examine that relationship formally. ${ }^{17}$

The estimation results in Table 11 point to a clear link between the form of government and income inequality: presidential regimes are associated with Gini coefficients between 12 and 24\% larger than those of parliamentary regimes. These results reconcile with those from Table 2 and Fig. 1. Similar to findings reported above, dropping variables measuring initial GDP, the size of government, or both, provide results quantitatively similar to those in Table 11. Finally, Table 12 presents similar results from applying instrumental variables and Heckman correction procedures. When those techniques are adopted, point estimates for the coefficients of interest increase in magnitude and are estimated with more precision.

Overall, our results in this section establish that macroeconomic outcomes in parliamentary regimes are superior to those under presidential systems. We find that growth is faster, that inflation is slower and less volatile, and income is distributed more equally in parliamentary systems.

\footnotetext{
17 Shugart (1999) is the only other study of which we know that links regime type to income inequality, albeit informally. By listing the sample countries according to their income inequalities, Shugart (1999) points to a strong tendency for incomes to be distributed more unequally under presidential regimes. Gregorini and Longoni (2009) look at the role of income inequality in the relationship between electoral rules and public consumption spending, finding that income inequality raises such spending in countries with proportional electoral systems, but has no effect in nations with majoritarian electoral rules. Gregorini and Longoni do not consider the potential implications of the form of government on income inequality.
} 
Table 11 Inequality and the form of government

\begin{tabular}{|c|c|c|c|c|c|c|c|c|c|}
\hline & (1) & (2) & (3) & (4) & (5) & (6) & (7) & (8) & (9) \\
\hline Pres & $\begin{array}{l}0.124 * * * \\
(0.004)\end{array}$ & $\begin{array}{l}0.130 * * * \\
(0.002)\end{array}$ & $\begin{array}{l}0.238 * * * \\
(0.000)\end{array}$ & $\begin{array}{l}0.164 * * * \\
(0.000)\end{array}$ & $\begin{array}{l}0.160 * * * \\
(0.000)\end{array}$ & $\begin{array}{l}0.208 * * * \\
(0.000)\end{array}$ & $\begin{array}{l}0.185^{* * * *} \\
(0.000)\end{array}$ & $\begin{array}{l}0.182 * * * \\
(0.000)\end{array}$ & $\begin{array}{l}0.211 * * * \\
(0.000)\end{array}$ \\
\hline $\begin{array}{r}\text { Semi- } \\
\text { pres }\end{array}$ & & $\begin{array}{l}-0.011 \\
(0.835)\end{array}$ & & & $\begin{array}{l}-0.012 \\
(0.796)\end{array}$ & & & $\begin{array}{l}-0.007 \\
(0.873)\end{array}$ & \\
\hline Maj & & & & $\begin{array}{l}0.077 * * \\
(0.037)\end{array}$ & $\begin{array}{l}0.061 \\
(0.103)\end{array}$ & $\begin{array}{l}0.023 \\
(0.593)\end{array}$ & $\begin{array}{l}0.067 * \\
(0.076)\end{array}$ & $\begin{array}{l}0.056 \\
(0.126)\end{array}$ & $\begin{array}{l}0.014 \\
(0.747)\end{array}$ \\
\hline GovtSize & & & & $\begin{array}{l}0.040 \\
(0.200)\end{array}$ & $\begin{array}{l}0.048 \\
(0.134)\end{array}$ & $\begin{array}{l}0.002 \\
(0.960)\end{array}$ & $\begin{array}{l}0.133 \\
(0.309)\end{array}$ & $\begin{array}{l}0.175 \\
(0.188)\end{array}$ & $\begin{array}{l}0.152 \\
(0.272)\end{array}$ \\
\hline Openness & & & & $\begin{array}{l}-0.003 \\
(0.939)\end{array}$ & $\begin{array}{l}0.001 \\
(0.971)\end{array}$ & $\begin{array}{l}-0.018 \\
(0.594)\end{array}$ & $\begin{array}{l}0.000 \\
(0.995)\end{array}$ & $\begin{array}{l}0.000 \\
(0.916)\end{array}$ & $\begin{array}{l}0.000 \\
(0.275)\end{array}$ \\
\hline $\begin{array}{r}\text { Initial- } \\
\text { GDP }\end{array}$ & & & & $\begin{array}{l}-0.022 \\
(0.560)\end{array}$ & $\begin{array}{l}-0.029 \\
(0.453)\end{array}$ & $\begin{array}{l}0.034 \\
(0.408)\end{array}$ & (0.737) & $\begin{array}{l}0.013 \\
(0.788)\end{array}$ & $\begin{array}{l}0.083 * \\
(0.060)\end{array}$ \\
\hline $\begin{array}{l}\text { Initial- } \\
\text { GDP }^{2}\end{array}$ & & & & $\begin{array}{l}-0.001 \\
(0.437)\end{array}$ & $\begin{array}{l}-0.001 \\
(0.422)\end{array}$ & $\begin{array}{l}-0.004 * * * \\
(0.008)\end{array}$ & $\begin{array}{l}-0.002 \\
(0.312)\end{array}$ & $\begin{array}{l}-0.002 \\
(0.300)\end{array}$ & $\begin{array}{l}-0.005^{* * * *} \\
(0.001)\end{array}$ \\
\hline $\begin{array}{c}\text { Human- } \\
\text { Cap }\end{array}$ & & & & & & & $\begin{array}{l}-0.071 * \\
(0.081)\end{array}$ & $\begin{array}{l}-0.074 * \\
(0.072)\end{array}$ & $\begin{array}{l}-0.087 * \\
(0.091)\end{array}$ \\
\hline Inflation & & & & & & & $\begin{array}{l}0.007 \\
(0.942)\end{array}$ & $\begin{array}{l}0.004 \\
(0.972)\end{array}$ & $\begin{array}{l}-0.002 \\
(0.978)\end{array}$ \\
\hline$R^{2}$ & 0.125 & 0.119 & 0.182 & 0.197 & 0.200 & 0.143 & 0.302 & 0.304 & 0.182 \\
\hline$N$ & 269 & 269 & 246 & 209 & 209 & 167 & 192 & 192 & 164 \\
\hline
\end{tabular}

A standard star convention is used, with $* * *$ and $* * *$ representing significance levels of 10,5 and $1 \%$ respectively. Dependent variable is the log of the mean Gini coefficient for income inequality over the period of the panel; all else is as defined earlier

Table 12 Inequality: instrumental variable and Heckman correction specifications

\begin{tabular}{|c|c|c|c|c|c|c|c|c|c|}
\hline & (1) & (2) & (3) & (4) & $(5)$ & (6) & (7) & (8) & (9) \\
\hline \multicolumn{10}{|c|}{ Instrumental variables } \\
\hline Pres & $\begin{array}{l}0.409 * * * \\
(0.000)\end{array}$ & $\begin{array}{l}0.402 * * * \\
(0.000)\end{array}$ & $\begin{array}{l}0.351 * * * \\
(0.000)\end{array}$ & $\begin{array}{l}0.582 * * * \\
(0.000)\end{array}$ & $\begin{array}{l}0.564 * * * \\
(0.000)\end{array}$ & $\begin{array}{l}0.420 \text { *** } \\
(0.000)\end{array}$ & $\begin{array}{l}0.478 * * * \\
(0.000)\end{array}$ & $\begin{array}{l}0.461 * * * \\
(0.000)\end{array}$ & $\begin{array}{l}0.391 * * * \\
(0.000)\end{array}$ \\
\hline Semi-pres & & $\begin{array}{l}0.015 \\
(0.886)\end{array}$ & & & $\begin{array}{l}0.220 \\
(0.112)\end{array}$ & & & $\begin{array}{l}0.144 \\
(0.158)\end{array}$ & \\
\hline $\begin{array}{l}\text { Sargan- } \\
\text { Hansen }\end{array}$ & 0.009 & 0.082 & 0.049 & 0.634 & 0.721 & 0.307 & 0.582 & 0.629 & 0.242 \\
\hline \multicolumn{10}{|c|}{ Heckman correction } \\
\hline Pres & $\begin{array}{l}0.191 * * * \\
(0.000)\end{array}$ & $\begin{array}{l}0.191 * * * \\
(0.000)\end{array}$ & $\begin{array}{l}0.157 * * * \\
(0.000)\end{array}$ & $\begin{array}{l}0.144 * * * \\
(0.000)\end{array}$ & $\begin{array}{l}0.204 * * * \\
(0.000)\end{array}$ & $\begin{array}{l}0.205^{* * *} \\
(0.000)\end{array}$ & $\begin{array}{l}0.213 * * * \\
(0.000)\end{array}$ & $\begin{array}{l}0.226 * * * \\
(0.000)\end{array}$ & $\begin{array}{l}0.214 * * * \\
(0.000)\end{array}$ \\
\hline Semi-pres & & $\begin{array}{l}-0.017 \\
(0.726)\end{array}$ & & & $\begin{array}{l}-0.032 \\
(0.414)\end{array}$ & & & $\begin{array}{l}-0.030 \\
(0.431)\end{array}$ & \\
\hline
\end{tabular}

A standard star convention is used, with $*, * *$ and $* * *$ representing significance levels of 10,5 and $1 \%$ respectively. Instrumental variable and Heckman correction estimation results for the variables of interest. Results similar to those presented in Table 11 now performing those procedures outlined in Sect. 3.1 


\subsection{Sensitivity}

We test the robustness of our results by entering a number of different explanatory variables in the specifications reported above. Both the level of democracy (Polity) and the stock of democratic experience (the number of consecutive years the country has been judged to be democratic, DemAge) are included in one of our robustness checks. In another, the continental indicator variables of PT are entered into the specifications to test for the role of geography; as Fig. 3 demonstrates, presidential regimes tend be concentrated in South America and Africa. A variable measuring the proportion of the population that practices a protestant religion also was tested, following the existing studies of religiosity and macroeconomic performance (see, for example, Becker and Woessmann 2009). In all cases, entering those variables into our previous specifications had limited effect on the quantitative estimates and statistical significances of the link between the form of government and macroeconomic outcomes. Estimates from these specifications can be found in the supplementary material ("Appendix 2").

We also re-estimated the instrumental variable and the Heckman correction procedures using the constitutional timing variables from Rockey (2012) (see Sect. 3.1 for a discussion of those variables) instead of those applied in PT. The re-estimations returned results similar to those presented above for both the instrumental variable and Heckman techniques. The instrumental variable specifications also were re-estimated with generalized methods of moments, which again yielded results similar to those above, with the same conclusions reached. See the supplementary materials ("Appendix 2") for those results.

\section{Conclusions}

This paper examines the link between the form of government (presidential or parliamentary) and macroeconomic performance using data from a large number of countries over the 1950-2015 period. Our set of measures include output growth and its volatility, inflation and its volatility, as well as income inequality. We find clear differences in outcomes under the two regimes studied. More specifically, we find that presidential regimes consistently are associated with inferior macroeconomic outcomes. Output growth is estimated to be between 0.6 and 1.2 percentage points lower, inflation is at least four percentage points higher and income is 12 to $24 \%$ more unequal under presidential systems than under parliamentary regimes.

Why do presidential regimes produce worse economic outcomes than parliamentary systems? To answer this question, it is crucial to understand the wider institutional context in which the two systems operate. It has long been recognized that institutions, whether political, legal or economic, play a key role on economic outcomes through aggregating conflicting interests into public policy and imposing constraints on economic behaviour. One can therefore envisage that constitutional rules shape economic outcomes through their role on the form of institutions and, in turn, through the influence of institutions on economic policy and hence economic performance. We believe that a systematic analysis of institutions across the two forms of government should form a key part of the attempt in answering this question and hence is an important task for future research.

Acknowledgements We would like to thank the editor and an anonymous referee whose comments greatly improved the paper. We would also like to thank John Carey, John Gerring, Bernd Hayo, Ersin Kalaycioglu, Arend Lijphart, Andrew Pickering, James Rockey, Murat Somer, Kamil Yilmaz and the participants at the Turkish Economic Association's Annual Conference, 20-22 October, 2016 in Bodrum, Turkey for helpful comments. We are grateful to James Rockey for sharing his dataset on the age of democracy and constitutional changes. 


\section{Compliance with ethical standards}

Conflict of interest The authors declare that they have no conflict of interest.

Open Access This article is distributed under the terms of the Creative Commons Attribution 4.0 International License (http://creativecommons.org/licenses/by/4.0/), which permits unrestricted use, distribution, and reproduction in any medium, provided you give appropriate credit to the original author(s) and the source, provide a link to the Creative Commons license, and indicate if changes were made.

\section{Appendix 1}

See Table 13 and Fig. 3.

Table 13 Data appendix (variables in order of appearance)

Dependent variables

\begin{tabular}{ll}
\hline GDP growth & Annual growth rate of GDP per capita; data obtained from the World Bank \\
GDP growth volatility & Standard deviation of 'GDP growth' (above) over the panel period \\
Inflation & GDP deflator as an annual percentage taken from the World Bank \\
Inflation volatility & Standard deviation of 'Inflation' above over the panel period \\
Gini coefficient & Gini coefficient measure of income inequality; data obtained from World Income \\
& Inequality Database \\
\hline
\end{tabular}

Independent variables

Pres

Semi-Pres

Maj

Initial GDP

Education

Fertility

LifeExp

Openness

GovtSize

ExRateVol

Polity

OpenVol
A measure determining if a country is operating under a presidential regime; data obtained from both BG and PT. A more detailed discussion of the definitions applied can be found in Sect. 2.2

A binary measure determining if a country is operating under a semi-presidential regime; data obtained from $\mathrm{BG}$. A more detailed discussion of the definition applied can be found in Sect. 2.2

A binary measure indicating if a country is operating under a majoritarian voting system; data obtained from BG

Log of GDP per capita (expressed in current United States Dollars) at the start of the panel period; data obtained from the World Bank

Metric of education measured as the average total number of years of educational attainment; data obtained from Barro and Lee (2013)

Log of the fertility rate expressed as the number of births per woman; data obtained from the World Bank

Log of the life expectancy at birth in years; data obtained from the World Bank

The sum of imports and exports expressed as a fraction of GDP; data obtained from the World Bank

Share of government consumption in total GDP; data obtained from Penn World Tables

Standard deviation of the exchange rate expressed as a fraction against the US dollar over the panel period; data obtained from Penn World Tables

Measure of democracy within a given country on a $(-10,10)$ scale; higher values relating to higher degrees of democracy and lower values indicating greater degrees of autocracy. Data obtained from the Polity IV Project

Standard deviation of 'Openness' (above) over the panel period 
Table 13 (continued)

Independent variables

\begin{tabular}{ll}
\hline CBI & Measure of central bank independence obtained from Cukierman et al. (1992), \\
& Polillo and Guillén (2005) and Crowe and Meade (2008), all of whom use the \\
& same methodology \\
Index of human capital per person, based on years of schooling and returns to \\
education; data obtained from the Penn World Table
\end{tabular}

Instrumental variables

$\begin{array}{ll}\begin{array}{l}\text { con2150, con5180, } \\ \text { con81 }\end{array} & \begin{array}{l}\text { Dummy variables measuring the date of when the constitution within a country } \\ \text { was established, using dummy variables for periods between 1921 and 1950, } \\ \text { between 1950 and 81, and beyond 1981. Variables obtained from PT as well } \\ \text { as Rockey (2012) who updates these to consider both when a constitution was } \\ \text { promulgated and when free elections were held under the constitution for the } \\ \text { first time } \\ \text { Fraction of the country which speaks one of the main European languages; data } \\ \text { obtained from Persson and Tabellini (2003) } \\ \text { EurFrac } \\ \text { Fraction of the country which speaks English; data obtained from PT } \\ \text { EngFrac } \\ \text { Latitude of the country's capital city; data obtained from PT } \\ \text { Deasure of the length of time in which the Polity score (see above) has been } \\ \text { positive nonstop; that is, how long a country has been consistently democratic } \\ \text { FrankRom }\end{array} \quad \begin{array}{l}\text { Predicted trade share of an economy, based on a gravity model of international } \\ \text { trade that only uses a country's population and geographical features adapted } \\ \text { from Frankel and Romer (1996); data obtained from Hall and Jones (1999) }\end{array} \\ & \end{array}$

Institutional variables

\begin{tabular}{|c|c|}
\hline Polity & See above in dependent variables \\
\hline DemAge & See above in instrumental variables \\
\hline PartDem & $\begin{array}{l}\text { A measure of the level to which democracy is participatory within a country; data } \\
\text { obtained from Varieties of Democracy database }\end{array}$ \\
\hline ElecDem & $\begin{array}{l}\text { A measure of the level to which the ideal of electoral democracy is achieved; data } \\
\text { obtained from Varieties of Democracy database }\end{array}$ \\
\hline MediaFree & $\begin{array}{l}\text { The degree to which media is free from government; data obtained from Varieties } \\
\text { of Democracy database }\end{array}$ \\
\hline ParComp & $\begin{array}{l}\text { A variable which measures the extent to which alternative preferences for policy } \\
\text { and leadership can be pursued in the political arena; data obtained from Polity IV } \\
\text { Project }\end{array}$ \\
\hline RuleOfLaw & $\begin{array}{l}\text { A variable measuring agents perceived confidence in the rule of law of a country, } \\
\text { in particular over contract enforcement, property rights, the police and the courts; } \\
\text { data obtained from the Worldwide Governance Indicators }\end{array}$ \\
\hline Xconst & $\begin{array}{l}\text { Measure of constraints on chief executive where lower numbers represent fewer } \\
\text { constraints; data obtained from the Polity IV Project. }\end{array}$ \\
\hline PolCon & $\begin{array}{l}\text { Measure of the feasibility of change in policy given the structure of a nation's } \\
\text { political institutions and the preference of the actors that inhabit them; data } \\
\text { obtained from the POLCON database }\end{array}$ \\
\hline Parties & $\begin{array}{l}\text { Effective number of electoral parties in an election where an average is taken over } \\
\text { the time period of the panel; data obtained from BG }\end{array}$ \\
\hline EthPol & $\begin{array}{l}\text { A measure of the polarisation of ethnicity in a given country; data obtained from } \\
\text { Reynal-Querol and Montalvo (2005) }\end{array}$ \\
\hline SocPart & $\begin{array}{l}\text { A measure of society participation through the degree to which policy makers } \\
\text { consult society; data obtained from Varieties of Democracy database }\end{array}$ \\
\hline
\end{tabular}


Table 13 (continued)

Institutional variables

CivLib A measure to the degree in which civil liberties are respected in a country; data obtained from Varieties of Democracy database

FreeSpeech A measure to the level in which individuals have freedom of speech within a country; data obtained from Varieties of Democracy database

FreeExp A variable measuring the level of respect governments give to media and press freedoms; data obtained from Varieties of Democracy database

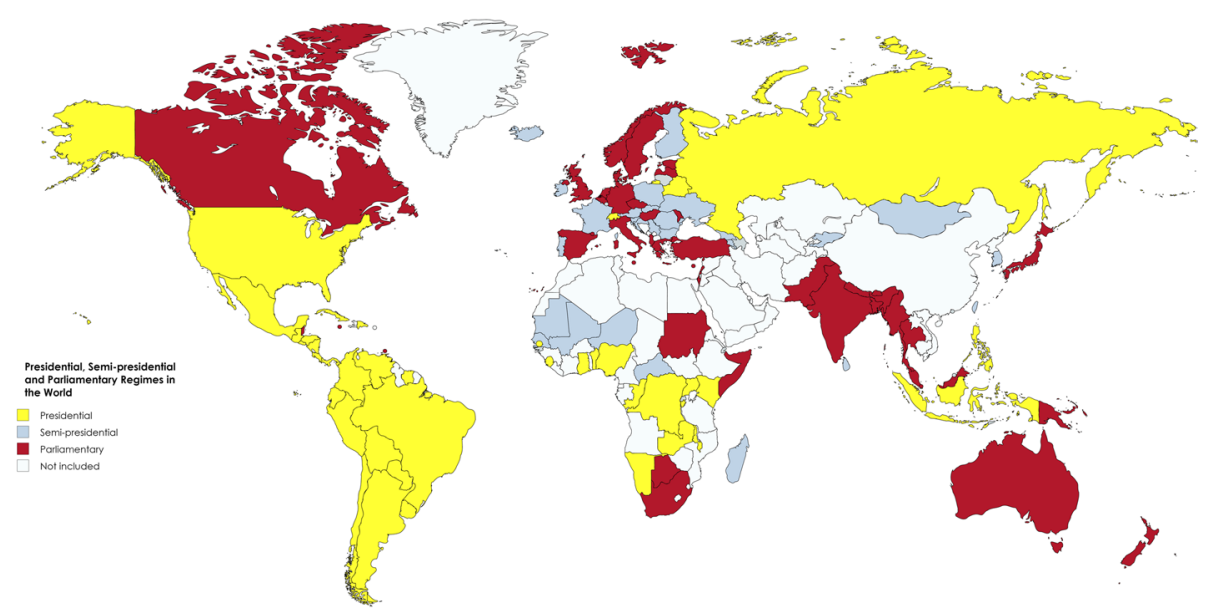

Fig. 3 Presidential, semi-presidential and parliamentary regimes. Map illustrating parliamentary, presidential and semi-presidential regimes using BG classification for government structures

\section{Appendix 2: Supplementary materials: sensitivity results}

\section{The role of democracy}

We test the robustness of our results to including both the level of democracy (Polity) and the stock of democratic experience (DemAge). Estimates for the variables of interest are presented in panel A of Table 14, which reports results using the eighth specification in Tables 4, 5, 6, 7, 8, 9, 10, 11 and 12. The two indicators of democracy themselves are estimated to have significant impacts on the volatility of GDP growth as well as on inflation and its volatility, with more democratic and older democracies predicted to influence those outcomes favorably. Despite this, as can be seen from Table 14, entering those variables has very little effect on the quantitative estimates and statistical significances of the link between the form of government and macroeconomic outcomes (a conclusion that also holds across different specifications, not just the eight from Tables 4, 5, 6, 7, 8, 9, 10, 11 and 12; those results are not reported). 
Table 14 Regression results from robustness tests

\begin{tabular}{|c|c|c|c|c|c|}
\hline & Growth & GrowVol & Inflation & InfVol & Inequality \\
\hline \multicolumn{6}{|c|}{ A. The stock and flow of democracy } \\
\hline Pres & $\begin{array}{l}-0.638 * * \\
(0.031)\end{array}$ & $\begin{array}{l}-0.046 \\
(0.895)\end{array}$ & $\begin{array}{l}0.051 * * \\
(0.019)\end{array}$ & $\begin{array}{l}0.024 * \\
(0.061)\end{array}$ & $\begin{array}{l}0.178 * * * \\
(0.000)\end{array}$ \\
\hline \multicolumn{6}{|c|}{ B. Geographic indicators } \\
\hline Pres & $\begin{array}{l}-0.170 \\
(0.613)\end{array}$ & $\begin{array}{l}-0.208 \\
(0.544)\end{array}$ & $\begin{array}{l}0.038 * \\
(0.095)\end{array}$ & $\begin{array}{l}0.025 * * \\
(0.037)\end{array}$ & $\begin{array}{l}0.091 * \\
(0.061)\end{array}$ \\
\hline \multicolumn{6}{|c|}{ C. The degree of Protestantism } \\
\hline Pres & $\begin{array}{l}-0.638^{* *} \\
(0.031)\end{array}$ & $\begin{array}{l}-0.046 \\
(0.895)\end{array}$ & $\begin{array}{l}0.051 * * \\
(0.019)\end{array}$ & $\begin{array}{l}0.024 * \\
(0.061)\end{array}$ & $\begin{array}{l}0.178 * * * \\
(0.000)\end{array}$ \\
\hline \multicolumn{6}{|c|}{ D. General methods of moments estimation } \\
\hline Pres & $\begin{array}{l}-1.505^{* * *} \\
(0.000)\end{array}$ & $\begin{array}{l}0.013 \\
(0.960)\end{array}$ & $\begin{array}{l}0.060 * \\
(0.059)\end{array}$ & $\begin{array}{l}0.028 * * \\
(0.031)\end{array}$ & $\begin{array}{l}0.328 * * * \\
(0.000)\end{array}$ \\
\hline
\end{tabular}

Robustness results when including additional variables in the analysis. Results presented from column (8) in Tables 4, 5, 6, 7, 8, 9, 10, 11 and 12 where only the estimated coefficients of the variable of interest have been presented. Similar results are obtained when using any of the nine specifications from Tables 4, 5, 6, 7, 8, 9, 10, 11 and 12 (not reported). In panel A 'Polity' and 'DemAge' are included in the specification; in panel B the regional dummy variables from PT are included in the specification; the specifications in panel $\mathrm{C}$ include the proportion of the population practicing a protestant faith; and panel D presents instrumental variable results using generalized methods of moments

\section{The role of geography}

As demonstrated in Fig. 3, presidential regimes tend be concentrated in South America and Africa. In order to test the robustness of results to geographical location, we apply PT's grouping and enter dummy variables for countries belonging to the OECD, along with regional indicators for nations in Latin and South America, Africa, and Southern and East Asian countries (leaving a benchmark group containing non-OECD European countries and those from the Middle East). In panel B of Table 14 we present results using the eight specifications in Tables 4, 5, 6, 7, 8, 9, 10, 11 and 12, now including these regional dummy variables.

Given the presence of collinearity between the regional dummy variables and the type of government, the statistical significance of our empirical results weaken. Lesser statistical significance is most noteworthy for the relationship between presidential regimes and economic growth: coefficient estimates change from being statistically significant at the $5 \%$ level (Table 4) to being insignificant, although the partial correlation remains negative. In all other cases, however, statistically significant results reported in earlier analyses are maintained and, hence, are robust to including regional dummy variables (that conclusion again holds in unreported estimates across different specifications, not just the eight one from Tables 4, 5, 6, 7, 8, 9, 10, 11 and 12). 


\section{The role of Protestantism}

We test the robustness of our results further by including the proportion of the population that practices a protestant religion, following the existing studies of religiosity and macroeconomic performance (see, for example, Becker and Woessmann 2009). The protestant population percentage is itself statistically significant and enters with a negative sign in regressions for which either inflation volatility or income inequality is the dependent variable. The impact of the form of government again remains unchanged (panel C in Table 14).

\section{Further sensitivity checks}

We also re-estimated the instrumental variable and Heckman correction procedures using the constitutional timing variables from Rockey (2012) (see Sect. 3.1 for a discussion of those variables) instead of those applied in PT (2003). These provide similar results to those presented above for both instrumental variable and Heckman techniques. We further perform the instrumental variable estimations using generalized methods of moments, which again provides similar results to those above, with the same conclusions reached (panel D in Table 14).

We have also explored the sensitivity of our findings to using panels still over fifteen years but starting in 1960 (as opposed to 1965 above), leading to quantitatively similar results for all dependent variables in the analysis. Point estimates can be larger, especially for growth and growth volatility coefficients; however, the fewer observations also leads to slightly weaker levels of significance. ${ }^{18}$ The results from above are also not sensitive to tenyear panels starting in 1960, with similar results obtained from these time periods.

\section{References}

Acemoglu, D. (2005). Constitutions, politics, and economics: A review essay on Persson and Tabellini's the economic effects of constitutions. Journal of Economic Literature, 43, 1025-1048.

Alesina, A., \& Perotti, R. (1996). Income distribution, political instability, and investment. European Economic Review, 40(6), 1203-1228.

Barro, R. (2007). Determinants of economic growth: A cross-country empirical study. Cambridge: The MIT Press.

Barro, R. J., \& Gordon, D. B. (1983). Rules, discretion and reputation in a model of monetary policy. Journal of Monetary Economics, 12(1), 101-121.

Barro, R. J., \& Lee, J. W. (2013). A new data set of educational attainment in the world, 1950-2010. Journal of Development Economics, 104, 184-198.

Becker, S. O., \& Woessmann, L. (2009). Was Weber wrong? A human capital theory of protestant economic history. The Quarterly Journal of Economics, 124(2), 531-596.

Bell, D. \& Machin, S. (2016). Brexit and wage inequality. Technical report, VOX EU.

Blume, L., Müller, J., Voigt, S., \& Wolf, C. (2009). The economic effects of constitutions: replicating-and extending-Persson and Tabellini. Public Choice, 139(1-2), 197-225.

Bormann, N.-C., \& Golder, M. (2013). Democratic electoral systems around the world, 1946-2011. Electoral Studies, 32(2), 360-369.

\footnotetext{
18 Paradoxically, the number of observations in the regressions decreases starting the time horizon earlier in 1960 (by approximately 15\%) as some countries do not have data starting this early, but do have data starting from a little later (1965). Starting the time horizon when we do in the regression results allows for the largest sample of 15-year time periods in our specifications.
} 
Buchanan, J. M., \& Tullock, G. (1962). The calculus of consent (Vol. 3). Ann Arbor: University of Michigan Press.

Campos, N. F., \& Nugent, J. B. (2002). Who is afraid of political instability? Journal of Development Economics, 67(1), 157-172.

Carey, J. M. (2008). Presidential versus parliamentary government. In C. Ménard \& M. M. Shirley (Eds.), Handbook of new institutional economics (pp. 91-122). Berlin, Heidelberg: Springer.

Cheibub, J. A., Gandhi, J., \& Vreeland, J. R. (2010). Democracy and dictatorship revisited. Public Choice, 143(1-2), 67-101.

Crowe, C., \& Meade, E. E. (2008). Central bank independence and transparency: Evolution and effectiveness. European Journal of Political Economy, 24(4), 763-777.

Cukierman, A., Web, S., \& Neyapti, B. (1992). Measuring the independence of central banks and its effect on policy outcomes. World Bank Economic Review, 6(3), 353-398.

Elgie, R. (2005). From Linz to Tsebelis: Three waves of presidential/parliamentary studies? Democratization, 12(1), 106-122.

Frankel, J. A. \& Romer, D. H. (1996). Trade and growth: An empirical investigation. NBER Working Paper (w5476).

Gerring, J., Thacker, S. C., \& Moreno, C. (2009). Are parliamentary systems better? Comparative Political Studies, 42(3), 327-359.

Gregorini, F. \& Longoni, E. (2009). Inequality, political systems and public spending. Technical report.

Hall, R. E., \& Jones, C. I. (1999). Why do some countries produce so much more output per worker than others? The Quarterly Journal of Economics, 114(1), 83-116.

Hayo, B., \& Voigt, S. (2010). Determinants of constitutional change: Why do countries change their form of government? Journal of Comparative Economics, 38(3), 283-305.

Knutsen, C. H. (2009). The economic growth effect of constitutions revisited. Technical report, Department of Political Science, University of Oslo.

Linz, J. J. (1990). The perils of presidentialism. Journal of Democracy, 1(1), 51-69.

Mainwaring, S., \& Shugart, M. S. (1997). Juan Linz, presidentialism, and democracy a critical appraisal. Comparative Politics, 29(4), 449-471.

OECD. (2015). In it together: Why less inequality benefits all. Paris: OECD Publishing.

Persson, T., \& Tabellini, G. E. (2003). The economic effects of constitutions. Cambridge: MIT press.

Polillo, S., \& Guillén, M. F. (2005). Globalization pressures and the state: The worldwide spread of central bank independence. American Journal of Sociology, 110(6), 1764-1802.

Reynal-Querol, M., \& Montalvo, J. G. (2005). Ethnic polarization, potential conflict and civil war. American Economic Review, 95(3), 796-816.

Rockey, J. (2012). Reconsidering the fiscal effects of constitutions. European Journal of Political Economy, 28(3), 313-323.

Rogoff, M. A. (2011). French constitutional law: Cases and materials. Durham: Carolina Academic Press.

Shugart, M. S. (1999). Presidentialism, parliamentarism, and the provision of collective goods in less-developed countries. Constitutional Political Economy, 10(1), 53-88.

Woodford, M. (2003). Interest and prices: Foundations of a theory of monetary policy. Princeton: Princeton University Press. 